\title{
Quality of Work Life Metrics as a Predictor of Job Satisfaction and Organizational Commitment: A Study with Special Reference to Information Technology Industry
}

\author{
Dr. M. Swapna \\ Assistant Professor,Ramaiah Institute of Management Studies,Bangalore,India \\ Email:roses4swapna@yahoo.co.in
}

\author{
Doi:10.5901/mjss.2015.v6n3s2p170
}

\begin{abstract}
Information Technology (IT) industry in India is playing a very important role in putting India on the global map. This industry has become one of the most significant growth catalysts for the Indian economy. Indian firms, across all other sectors, largely depend on the IT service providers to make their business processes efficient. NASSCOM expects the IT services sector in India to grow by 13-14 per cent in 2013-14 and to touch US\$ 225 billion by 2020. The major strength of IT industry lies in its human resources. Human resources play a pivotal role in the success of the IT industry. Today's IT industry concentrates on its so called intellectual capital for enhancing its growth. They make the employees committed and satisfied through providing a satisfactory quality of work life. QWL in IT industry influences job satisfaction and organizational commitment to a greater extent as compared to other industry.
\end{abstract}

Keywords: Quality of Work Life, Organizational Commitment, Job Satisfaction

\section{Introduction}

The topic chosen for the study is "Quality of Work Life Metrics as a Predictor of Job Satisfaction \& Organizational Commitment: A Study with Reference to Information Technology Industry". Today, most of the IT companies have realised that QWL improves employee motivation, job performance, organizational commitment and productivity.

Most of the research conducted in the field of the quality of work life has focused on increasing employees' motivation to work harder and produce more, fostering loyalty and creating more effective organizations. Past studies have concentrated on reducing or eliminating costs involved in absenteeism and the subsequent loss in revenue, for the benefit of the organization. At the same time, investigations have given attention to guaranteeing job security, better remuneration and a safer work environment for employees.

In an article entitled Strategic approaches to work/life balance in Work life Report (2000), mention is made of organizations, which have taken a strategic, systematic approach to addressing work/life issues. Such organizations were able to report significant business gains, such as greater retention, increased productivity, commitment and customer service and reduced absenteeism.

In 2010 Normala and Daud investigated the relationship between quality of work life and organizational commitment amongst employees in Malaysian firms and say that the quality of work life of employees is an important consideration for employers interested in improving employee's job satisfaction and commitment.

There are number of studies which focused on the QWL as variable, movement, construct and as an outcome. But only few studies had identified the essential components of quality of working life. From the past studies it is also found that no study pinpointed QWL as a predictor of job satisfaction and organizational commitment in the IT industry. Hence this is a pioneer attempt by the researcher. It is also stressed that this study will bring lot of benefits to IT industry as it will pave the way for increasing job satisfaction and organizational commitment. Hence the emergence of this study.

\section{Objectives of the Study}

The study is undertaken with the following objectives.

For the purpose of this study, the researcher had chosen the top three IT companies as per NASSCOM survey form Bangalore city which is called Silicon Valley of India. It is a much known fact that most of the IT companies in and around the globe are housed in Bangalore, in areas that are named as Software Technology Park of India (STPI), Electronics City, and International Tech Park of Bangalore (ITPB). This study will highlight the relationship between QWL, 
job satisfaction and organizational commitment in Bangalore city in the top three IT companies viz, TCS, Infosys and Wipro.

Following are the objectives of the study.

- To examine the level of employees quality of work life in information technology industry.

- To identify the level of employee's job satisfaction in information technology industry.

- To identify the level of employee's organizational commitment in information technology industry

- To analyse quality of work life as a predictor of employees job satisfaction \& organizational commitment in information technology industry

- To investigate whether quality of work life, Job satisfaction \& employee commitment is effective irrespective of the demographical characteristics of employees like age, gender, marital status and work experience levels.

- To elicit the impact of quality of work life on job satisfaction and organizational commitment

\section{Research Methodology}

\subsection{Type of the Study}

The type of study undertaken for this research is of descriptive type, where the QWL metrics as a predictor of job satisfaction and organizational commitment prevailing in IT industry was analyzed in depth. Three IT Companies are taken as the case units.

\subsection{Tools Used}

Tools used in this study for the collection of data were the well designed questionnaire developed by LEIDEN and Meyer and Allen. The independent variable quality of work life is measured using Leiden QWL scale using the 59 items questionnaire which was constructed to assess work characteristics from two influential occupational stress models, the Job Demand Control Support model (Johnson \& Hall, 1988; Johnson, 1989; Karasek \& Theorell, 1990) and the Michigan model (Caplan, Cobb, French, van Harrison \& Pinneau, 1975).

The dependent variable in this study is employees Organizational Commitment. The overall organizational commitment is measured using the 18-item Revised questionnaire developed by (Meyer, Allen and Smith 2004), designed to measure Affective commitment, Normative commitment and Continuance commitment. The dependent variable job satisfaction is measured in the independent variable QWL as an outcome measure.

Although the Leiden Quality of Work Life Questionnaire consists of 12 work characteristics or dimensions, for this research it was only decided to use the first eleven. This was because the twelfth factor job satisfaction is considered to be an outcome variable of QWL.

\subsection{Pilot Testing}

A well designed questionnaire was administered among 40 respondents in the top three IT companies TCS, Infosys and Wipro as per NASSCOM survey 2012. The Cronbach's Alpha value for reliability of the instruments QWL, organizational commitment and job satisfaction were $0.876,0.824 \& 0.897$ respectively. The results from ANOVA signify that there exists a relationship between QWL and employee's organizational commitment.

The R Square value 0.609 indicates that the model is fit for estimation. From Pearson correlation the items Hazardous Exposure, Job Insecurity and Physical Exertion reported negative correlation with organizational commitment which indicated inverse relationship and all other items indicate positive relationship. Finally the questionnaire was subject to lot of modifications as suggested by the experts. Then the questionnaire was corrected and revised to prove the reliability and validity of the information collected.

\subsection{Methods of Collecting Data}

The researcher collected both primary and secondary data for the purpose of the study. Primary data was collected with a well defined questionnaire whereas the secondary data was collected with the help of journals, company reports, NASSCOM survey, company press releases, library and websites etc. 


\section{Sampling Design}

\subsection{Method of Sampling}

For the purpose of collection of data the researcher had used convenience sampling method. As per the convenience random sampling method; the researcher had selected $10 \%$ of the total operational executives in each company (from the three case units) at random for arriving at the reliability and validity of the data collected.

\subsection{Sample Size}

Among the 4113 operational executives the researcher had chosen 10\% from the total population belonging to each company. The following table shows the sample size of each company chosen.

Table 1: Sample Size Chosen for the Study

\begin{tabular}{|c|c|c|}
\hline Company & Operational Executives Total Population & Sample Size Total 410 Respondents \\
\hline TCS & 1652 & 165 \\
\hline INFOSYS & 1235 & 123 \\
\hline WIPRO & 1226 & 122 \\
\hline
\end{tabular}

\section{Statistical Techniques Used}

The researcher made use of mean, standard deviation for each item. The researcher also adopted correlations to find out whether there exists inter correlation among the various dimensions.

The researcher carried out an Analysis of variance to determine the impact of demographic variables on QWL, organizational commitment and job satisfaction. The researcher adopted regression model to find out the linear relationship between the QWL dimensions and organizational commitment dimensions.

\section{Reliability Score}

The reliability of the instrument is tested and the alpha value obtained for QWL (0.90), organizational commitment (0.91) and job satisfaction (0.94). These values are higher than the acceptable lower limit of 0.6 according to Nunnally.J.C (1978).

\begin{tabular}{|c|c|}
\hline Cronbach's Alpha Value for Dimensions and Variables & Alpha \\
\hline Skill Discretion & .87 \\
\hline Decision Authority & .82 \\
\hline Task Control & .91 \\
\hline Work And Time Pressure & .98 \\
\hline Role Ambiguity & .94 \\
\hline Physical Exertion & .78 \\
\hline Hazardous Exposure & .80 \\
\hline Job Insecurity & .92 \\
\hline Lack Of Meaningfulness & .91 \\
\hline Supervisor Social Support & .97 \\
\hline Co-Workers Social Support & .83 \\
\hline Quality Work Life & .90 \\
\hline Affective & .89 \\
\hline Continuance & .91 \\
\hline Normative & .94 \\
\hline Organizational Commitment & .91 \\
\hline Job Satisfaction & .94 \\
\hline
\end{tabular}




\section{Research Hypothesis}

In determining QWL, job satisfaction and organizational commitment the focus was laid on demographic variables and determinants which showed a significant difference. Thus the following null hypothesis was formulated.

H1: There is no significant difference in quality of work life across different age groups of the respondents.

H2: There is no significant difference in quality of work life with the gender of the respondents.

H3: There is no significant difference in quality of work life with the marital status of the respondents.

H4: There is no significant difference in quality of work life with the work experience level of the respondents.

H5: There is no significant difference in organizational commitment across different age groups of the respondents.

H6: There is no significant difference in organizational commitment with the gender of the respondents.

H7: There is no significant difference in organizational commitment with the marital status of the respondents.

H8: There is no significant difference in organizational commitment with the work experience level of the respondents.

H9: There is no significant difference in job satisfaction across different age groups of the respondents.

H10: There is no significant difference in job satisfaction with the gender of the respondents.

H11: There is no significant difference in job satisfaction with the marital status of the respondents.

\section{Findings and Suggestions}

After fine tuning the data collected, the results were summarized in the analysis and interpretation chapter $v$.On proper scrutiny of the analysis and interpretation it was very obvious that QWL was found to be significantly correlated with the job satisfaction and organizational commitment.

The findings and suggestions are summarized below.

The statistics results showed that the QWL had an overall mean score of 3.41, for organizational commitment it showed 3.97 and for job satisfaction it showed 3.54 .This results indicates that there exists a moderate status of QWL, organizational commitment and job satisfaction in the study organization.

Table 3: Mean score of the QWL Dimensions

\begin{tabular}{|c|c|c|}
\hline S.NO & Dimensions & Mean Score \\
\hline 1 & Skill discretion & 3.90 \\
\hline 2 & Decision authority & 3.47 \\
\hline 3 & Task control & 3.69 \\
\hline 4 & Work and time pressure & 3.47 \\
\hline 5 & Role ambiguity & 3.68 \\
\hline 6 & Physical exertion & 3.02 \\
\hline 7 & Hazardous exposure & 2.70 \\
\hline 8 & Job insecurity & 2.92 \\
\hline 9 & Lack of meaningfulness & 3.52 \\
\hline 10 & Supervisor social support & 3.52 \\
\hline 11 & Co-workers social support & 3.64 \\
\hline
\end{tabular}

From the above table it is evident that the dimensions hazardous exposure and job insecurity indicate a low status. The mean score of affective commitment is 3.80 , continuance commitment is 3.93 and normative commitment is 4.17 which indicate good status of organizational commitment in the organization. The mean score of job satisfaction is 3.54 which indicate moderate status.

Hence it can be concluded that the companies need to focus more on the areas like hazardous exposure and job security which requires significant attention. On the other hand skill discretion is found to be high which indicate that the respondents have a challenging work environment.

\section{Findings from Analysis of Variance}

The researcher carried out an ANNOVA to check whether there exist significant differences with demographic variables (gender, age, marital status and work experience level) and their perception towards QWL, job satisfaction and 
organizational commitment.

Table 4: ANOVA for Gender

\begin{tabular}{|c|c|c|c|c|c|c|}
\hline & & $\mathrm{N}$ & Mean & Std. Deviation & $\mathrm{F}$ & Sig. \\
\hline \multirow{3}{*}{ Quality of Work Life } & Male & 174 & 3.35 & 0.30 & \multirow{3}{*}{16.94} & \multirow{3}{*}{$0.00^{*}$} \\
\hline & Female & 236 & 3.45 & 0.19 & & \\
\hline & Total & 410 & 3.41 & 0.25 & & \\
\hline \multirow{3}{*}{ Organization Commitment } & Male & 174 & 3.87 & 0.53 & \multirow{3}{*}{6.32} & \multirow{3}{*}{$0.01^{*}$} \\
\hline & Female & 236 & 4.05 & 0.80 & & \\
\hline & Total & 410 & 3.97 & 0.70 & & \\
\hline \multirow{3}{*}{ Job Satisfaction } & Male & 174 & 3.40 & 0.48 & \multirow{3}{*}{27.94} & \multirow{3}{*}{$0.00^{*}$} \\
\hline & Female & 236 & 3.63 & 0.41 & & \\
\hline & Total & 410 & 3.54 & 0.46 & & \\
\hline
\end{tabular}

*: Significant at $5 \%$ level

From the above values, it is obvious that the significance values for $\mathrm{QWL}(0.00)$,organizational commitment $(0.01)$ and job satisfaction (0.00) is less than 0.05 , hence the null hypothesis is rejected and therefore it can be concluded there exists a significant differences in gender and their perception towards QWL, job satisfaction and organizational commitment.

Hence it is suggested that companies shall frame HR policies based on the gender, so that a good QWL can be established to enhance job satisfaction and organizational commitment

Table 5: ANOVA for Age Group

\begin{tabular}{|c|c|c|c|c|c|c|}
\hline & & $\bar{N}$ & Mean & Std. Deviation & $F$ & Sig. \\
\hline \multirow{5}{*}{ Quality of Work Life } & $20-25 \mathrm{yrs}$ & 144 & 3.28 & 0.12 & \multirow{5}{*}{104.72} & \multirow{5}{*}{$0.00^{*}$} \\
\hline & $26-30$ & 123 & 3.48 & 0.28 & & \\
\hline & $31-35$ & 123 & 3.39 & 0.14 & & \\
\hline & $40+$ & 21 & 4.03 & 0.00 & & \\
\hline & Total & 410 & 3.41 & 0.25 & & \\
\hline \multirow{5}{*}{ Organization Commitment } & $20-25 \mathrm{yrs}$ & 144 & 4.10 & 0.67 & \multirow{5}{*}{35.36} & \multirow{5}{*}{$0.00^{*}$} \\
\hline & $26-30$ & 123 & 4.20 & 0.75 & & \\
\hline & $31-35$ & 123 & 3.50 & 0.47 & & \\
\hline & $40+$ & 21 & 4.53 & 0.20 & & \\
\hline & Total & 410 & 3.97 & 0.70 & & \\
\hline \multirow{5}{*}{ Job Satisfaction } & $20-25$ yrs & 144 & 3.45 & 0.48 & \multirow{5}{*}{3.86} & \multirow{5}{*}{$0.01^{*}$} \\
\hline & $26-30$ & 123 & 3.63 & 0.51 & & \\
\hline & $31-35$ & 123 & 3.52 & 0.39 & & \\
\hline & $40+$ & 21 & 3.67 & 0.00 & & \\
\hline & Total & 410 & 3.54 & 0.46 & & \\
\hline
\end{tabular}

*: Significant at $5 \%$ level

From the above values, it is obvious that the significance values for $\mathrm{QWL}(0.00)$,organizational commitment $(0.00)$ and job satisfaction (0.01) is less than 0.05 , hence the null hypothesis is rejected and therefore it can be concluded there exists a significant differences among the Age groups and their perception towards QWL, job satisfaction and organizational commitment. satisfaction.

Hence it is found that, higher the age group showed higher status of QWL, organizational commitment and job 
Table 6: ANOVA for Marital Status

\begin{tabular}{|c|c|c|c|c|c|c|}
\hline & & $\mathrm{N}$ & Mean & Std. Deviation & $\mathrm{F}$ & Sig. \\
\hline \multirow{3}{*}{ Quality of Work Life } & Single & 164 & 3.26 & 0.17 & \multirow{3}{*}{124.42} & \multirow{3}{*}{$0.00^{*}$} \\
\hline & Married & 246 & 3.51 & 0.24 & & \\
\hline & Total & 410 & 3.41 & 0.25 & & \\
\hline \multirow{3}{*}{ Organizational Commitment } & Single & 164 & 3.91 & 0.63 & \multirow{3}{*}{2.51} & \multirow{3}{*}{0.11} \\
\hline & Married & 246 & 4.02 & 0.75 & & \\
\hline & Total & 410 & 3.97 & 0.70 & & \\
\hline \multirow{3}{*}{ Job Satisfaction } & Single & 164 & 3.31 & 0.40 & \multirow{3}{*}{78.22} & \multirow{3}{*}{$0.00^{*}$} \\
\hline & Married & 246 & 3.68 & 0.43 & & \\
\hline & Total & 410 & 3.54 & 0.46 & & \\
\hline
\end{tabular}

*: Significant at $5 \%$ level

From the above values, it is obvious that the significance values for QWL $(0.00)$ and job satisfaction $(0.00)$ is less than 0.05 , hence the null hypothesis is rejected and therefore it can be concluded there exists a significant differences in the marital status of the respondents and their perception towards QWL and Job satisfaction. But in case of organizational commitment the significance value (0.11) is greater than 0.05 , hence null hypothesis is accepted and can be concluded that irrespective of marital status organizational commitment remains the same.

Therefore it is found that employees, who are matured enough irrespective of their marital status, are prone to have higher commitment in the Organization.

Table 7: ANOVA for Work Experience Levels

\begin{tabular}{|c|c|c|c|c|c|c|}
\hline & & $\mathrm{N}$ & Mean & Std. Deviation & $F$ & Sig. \\
\hline \multirow{5}{*}{ Quality of Work Life } & 1 to 2 years & 103 & 3.36 & 0.20 & \multirow{5}{*}{34.18} & \multirow{5}{*}{$0.00^{*}$} \\
\hline & 2 to 3 & 144 & 3.30 & 0.19 & & \\
\hline & 3 to 4 & 41 & 3.46 & 0.00 & & \\
\hline & 4 plus years & 123 & 3.56 & 0.30 & & \\
\hline & Total & 410 & 3.41 & 0.25 & & \\
\hline \multirow{5}{*}{ Organizational Commitment } & 1 to 2 years & 103 & 4.05 & 0.85 & \multirow{5}{*}{19.87} & \multirow{5}{*}{$0.00^{*}$} \\
\hline & 2 to 3 & 144 & 4.09 & 0.55 & & \\
\hline & 3 to 4 & 41 & 3.22 & 0.34 & & \\
\hline & 4 plus years & 123 & 4.03 & 0.67 & & \\
\hline & Total & 410 & 3.97 & 0.70 & & \\
\hline \multirow{5}{*}{ Job Satisfaction } & 1 to 2 years & 103 & 3.67 & 0.35 & \multirow{5}{*}{19.31} & \multirow{5}{*}{$0.00 *$} \\
\hline & 2 to 3 & 144 & 3.46 & 0.54 & & \\
\hline & 3 to 4 & 41 & 3.90 & 0.10 & & \\
\hline & 4 plus years & 123 & 3.39 & 0.41 & & \\
\hline & Total & 410 & 3.54 & 0.46 & & \\
\hline
\end{tabular}

*: Significant at $5 \%$ level

From the above values, it is observed that the significance values for QWL $(0.00)$, organizational commitment $(0.00)$ and job satisfaction (0.00) is less than 0.05 , hence the null hypothesis is rejected and therefore it can be concluded there exists a significant differences in the work experience level and their perception towards QWL, job satisfaction and organizational commitment. Therefore it can be concluded that all three variables vary on the situational basis, depends on the case.

\section{Direction for Further Research}

- Having found that QWL dimensions leads to organizational commitment and job satisfaction further research can focus on how and why it influences.

- Further insight on other factors that contribute to organizational commitment can be studied.

- Quantitative studies on QWL are highly required in Indian context.

- Sector specific studies could also be carried out for the extension of such effectiveness-based research. 
- The complementing feature of QWL on organizational commitment and job satisfaction could be analyzed.

- Multidisciplinary approach on QWL, organizational commitment and job satisfaction could be studied.

- The congruence and link between QWL and productivity could be analyzed.

\section{References}

Adhikari, D.R \& Gautam(2005). D.K. Labor legislations for improving quality of work life in Nepal, International Journal of Law and Management, 52(1), 2010, 40-53.

Adhikari, D.R \& Gautam, D.K. (2010). Labor legislations for improving quality of work life in Nepal. International Journal of Law and Management, 52(1), 2010, 40-53.

Alireza Bolhari,Ali Rezaeean,, Jafar Bolhari,Sona Bairamzadeh and Amir Arzi Soltan(2011). The relationship between quality of work life and demographic characteristics of information technology staffs, International Conference on Computer Communication and Management, vol.5,pp-374-378.

Annandale, H.J., \& Pienaar, P.E. (2004) .Personality traits and integrity of applicants for security positions. Paper presented at the 2nd South African Work Wellness Conference. Potchefstroom, South Africa, 26 May 2004.

Aranya, N., Kushnir, T., \& Valency, A. (1986). Organizational commitment in a male-dominated profession, Human Relations, 39, $433-448$.

Arnold, H.J. \& Feldman, D.C. (1996). Organizational Behaviour. McGraw Hill

Ashoob, Taghi. (2006). Study of The Relationship between Quality of Work Life and Organizational Commitment of The High Schools of Gonbad-e- Kavus City, master's dissertation.

Baba, VV and Jamal, M (1991). Reutilization of job context and job content as related to employee"s quality of working life: a study of psychiatric nurses, Journal of organizational behavior. 12.pp- 379-386.

Barnett, R.C., \& Brennan, R.T. (1995). The relationship between job experiences and psychological distress: A structural equation approach, Journal of Oreganizational Behaviour,16, 259276.

Bearfield, S (2003) .Quality of Working Life, Aciirt Working paper 86. University of Sydney.

Beck, A.T., Ward, C.H., Mendelson, M., Mock, J. \& Erbaugh, J. (1961), "An inventory of measuring depression". Archives of General Psychiatry, 1, 56171.

Beckman, L.J. (1981). Effects of social interaction and children's relative inputs on older women's psychological wellbeing, Journal of Personality and Social Psychology, 41.

Behson, S.J. (2005). The relative contribution of formal and informal organizational work family support, Journal of Vocational Behaviour, 66.

Benkhoff, (1997). Disentangling organizational commitment: The dangers of the OCQ for research and policy, Personnel Review, Vol. 26 Iss: $1 / 2$

Benkhoff, (1997).Disentangling organizational commitment: The dangers of the OCQ for research and policy, Personnel Review, Vol. 26 Iss: $1 / 2$

Boisvert, M. (1977). La qualite de vie au travail (Ecole des Hautes Etudes Commerciales, Montreal).

Cohen, S.G., Chang, L., \& Ledford, G.E. (2003). A hierarchival construction of self - management leadership and its relationship to quality of work life and perceived work group effectiveness. Personnel Psychology, 50(2), 275308.

Considine, G., \& Callus, R. (2002). The Quality of Work Life of Australian Employees - the development of an index. University of Sydney, 215.

Daud, Normala(2010). Investigating the relationship between quality of work and organizational commitment among employees in Malaysian firm. International Journal of Business and conditions, gender and life quality. Social Problems, 47(3), 291-327.

Davis, K.G., Marras, W.S., Haney, C.A., Waters, T.R., \& Gupta, P. (2002). The impact of mental health processing and pacing on spine loading. 2002 Volvo Award in biomechanics. Spine, 27(23), 26452653.

Davis, L.E., \& Cherns, A.B. (1975). The quality of working life. New York: Free Press.

Davis, L.E., \& Trist, E.L. (1974). Improving the quality of working life: Sociotechnical case studies. In J. O'Toole (Ed.), Work and the quality of life: Resource papers for Work in America. (pp. 246284). Cambridge, MA: MIT Press.

De Wiite, H. (1999). Job insecurity and psychological wellbeing. Review of the literature and exploration of some unresolved issues. European Journal of Work and Organizational Psychology, 8, 155177

Dessler, G. (1981). Personnel management. Reston Publshing Company: Reston.

Diener, E. (1984), Subjective wellbeing. Psychological Bulletin, 95, 542575.

Diener, E. (2000). Subjective wellbeing: the science of happiness and a proposal for a national index". In M.E.P. Seligman and M. Csikszentmihalyi (ed.), Special issue on happiness, excellence and optimal human functioning. American Psychologist, 55, 3443.

Diener, E., \& Fujita, F. (1995). Resources, personal strivings, and subjective wellbeing: A nomothetic and idiographic approach". Journal of Personality and Social Psychology,68, 926-935.

Dolan, S. L., van Amerigaen, M. R., \& Arsenault, A. (1992). The role personality and social support in the etiologyof workers' stress and psychological strain. Industrial Relations (Canada), 47(1).

Dolan, S.L., Garcia, S., Cabezas, S., \& Tzafrir, S.S. (2008). Predictors of quality of work and poor health among primary healthcare personnel in Catalonia. International Journal of Health Care Quality Assurance, 21(2), 203

Nunnally,J.C.,(1978),Psychometric Theory(2nd ed.),New York,McGraw-Hill.

Redlich .C.A. (Ed.), Textbook of clinical occupational and environmental medicine, 34,549563.

Schein, E. (1970).Organizational culture and leadership. San Francisco: Jossey-Bass. 